\title{
INVESTIGATION OF ADNAN MENDERES FROM THE ELITE THEORY PERSPECTIVE ${ }^{12}$
}

\author{
Kafkas University \\ Economics and Administrative \\ Sciences Faculty \\ KAUJEASF \\ Article Submission Date: 09.08.2021 \\ Accepted Date: 29.10.2021 \\ Vol. 12, Issue 24, 202 \\ ISSN: $1309-4289$ \\ E - ISSN: 2149-9136
}

\author{
Hakan ÖZDEMIR \\ Assoc. Prof. \\ Inonu University \\ Faculty of Economics and \\ Administrative Sciences, \\ Malatya, Turkey \\ hakan.ozdemir@inonu.edu.tr \\ ORCID ID: 0000-0001-8973-1608
}

\section{Cevdet COŞKUN}

Political Science and International

Relations Specialist,

Inönü University

Malatya, Turkey

cevdetcoskun75@gmail.com

ORCID ID: 0000-0003-3932-6924
ABSTRACTI In the present study, the purpose was to examine Adnan Menderes from the perspective of Elite Theory. For this purpose, Historical Research, Content Analysis, and Leader Analysis Methods were employed in the study. After information was provided about the elite and the Elite Theory in the study, the life of Menderes was examined in terms of the Elite Theory. At the end of the study, it was concluded that Menderes, who was a socio-economic and political elite, was banned from power "by force" in line with Pareto's "Elite Rotation Theory". It was determined that when Menderes was in the ruling elite position, he acted in line with Michels' Bronze Law Theory of Oligarchy. Finally, it was also concluded that the negative relations of Menderes with other elites were contrary to Mills' Power Elite Theory.

Keywords: Adnan Menderes, elite, elite theory Jel codes: D91, H83, Z13

Scope: Political Sciences and Public Administration

Type: Research

DOI: 10.36543/kauiibfd.2021.044

Cite this Paper: Özdemir, H. \& Coşkun, C. (2021). Investigation of Adnan Menderes from the elite theory perspective. KAUJEASF, 12(24), 1079-1107.

\footnotetext{
${ }^{1}$ This study was prepared by making use of the master's thesis with the title "Comparison of Adnan Menderes and Turgut Özal from the Perspective of Elite Theory" that was written in the Department of Political Sciences and International Relations of the Institute of Social Sciences at Inonu University in 2021.

${ }^{2}$ It has been declared that the relevant study complies with ethical rules.
} 


\section{ELITT TEORISII PERSPEKTIFINDEN ADNAN MENDERES'IN INCELENMESI}

\section{Makale Gönderim Tarihi: 09.08.2021 \\ Hakan ÖZDEMIR \\ Doç. Dr. \\ İnönü Üniversitesi \\ İktisadi ve İdari Bilimler Fakültesi, Malatya, Türkiye \\ hakan.ozdemir@inonu.edu.tr}

ORCID ID: 0000-0001-8973-1608

\section{Cevdet COŞKUN}

Siyaset Bilimi ve Uluslararası İlişkiler Uzmanı, İnönü Üniversitesi Malatya, Türkiye cevdetcoskun75@gmail.com ORCID ID: 0000-0003-3932-6924
Yayına Kabul Tarihi: 29.10.2021

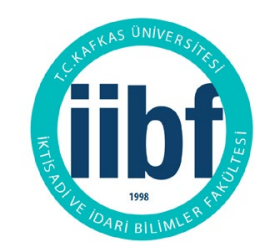

Kafkas Üniversitesi İktisadi ve İdari Bilimler Fakültesi KAÜIİBFD

Cilt, 12, Say1 24, 2021

ISSN: $1309-4289$

E-ISSN: 2149-9136

\section{ÖZI Bu çalışmada Elit Teorisi}

perspektifinden Adnan Menderes' in incelenmesi amaçlanmıştır. Bu amaçla sürdürülen çalışmada tarihsel araştırma, içerik analizi ve lider analizi yöntemlerinden yararlanılmıştır. Çalışmada elit ve Elit Teorisi hakkında bilgi verildikten sonra, Menderes'in hayatı Elit Teorisi bakımından incelenmiştir. Çalışmanın sonunda; bir sosyoekonomik ve siyasi elit olan Menderes'in, Pareto'nun "Elit Dolaşımı Teorisi" uyarınca iktidardan 'zor yoluyla' uzaklaştırıldığ1 görülmüştür. Ayrıca Menderes’in yönetici elit konumundayken Michels'in Oligarşinin Tunç Yasası Teorisi'ne uygun tasarruflarda bulunduğu tespit edilmiştir. Son olarak Menderes'in diğer elitlerle kurduğu olumsuz ilişkilerin, Mills'in İktidar Eliti Teorisi'ne aykırı olduğu sonucuna varılmıştır.

Anahtar Kelimeler: Adnan Menderes, elit, elit teorisi.

JEL Kodu: D91, H83, Z13

Alan: Siyaset Bilimi ve Kamu Yönetimi

Türü: Araştırma 


\section{INTRODUCTION}

The origin of the Elite Theory can be traced back to Plato, who said that "Kings must be philosophers, and philosophers kings". However, those who discussed this theory as a phenomenon were mostly Classical Elitists such as Gaetano Mosca, Vilfredo Pareto, and Robert Michels. The association of Elite Theory with democracy, and in this sense, its becoming debatable again in the $21^{\text {st }}$ Century, was made possible after the theories that were developed by Contemporary Elitists such as Harold D. Laswell, Raymond Aron, and C. Wright Mills. The main study fields of Elite Theory, which was developed with the contributions of the thinkers mentioned above, are power relations and power structures in societies. The purpose of the present study was to examine Adnan Menderes, who represented the milestone of center-right politics in Turkish political life, from the perspective of Elite Theory. In this respect, the relations of Adnan Menderes with elitism will be discussed in both socio-economic and political terms.

A literature review was conducted in the study by scanning the written sources in the printed and electronic media on the pre-political and political life of Menderes. The data obtained in the study will be analyzed by using the historical study, content analysis, and leader analysis methods, and the aspects of Menderes that can be evaluated in the scope of "elite" will be identified. In this sense, the purpose is to uncover whether -or to what extent- Menderes conformed to the "virtuous ruler" of Al-Farabi, and to the "subjected property" and "political property" of Ibn Haldun definitions. It will also be determined in which aspects it should be included in the "elite scope" that was foreseen by Mosca and Pareto, and whether the political organization he led was prone to the corruption that was described in the Bronze Law of Oligarchy of Michels. In addition to these, it will also be determined to what extent it was compatible with the Elite Theory in terms of relations with the "Power Elite", which Mills argued that it should be cooperated with.

The study was organized as follows; the elite and the elite theory will be discussed in the next section. The pre-political and political life of Adnan Menderes will be discussed in the third part of the study, and the study will be completed with a conclusion part.

\section{ON THE ELITE AND THE THEORY OF ELITE}

"Elite" is a concept that is derived from the Latin word "eligere", which means "to choose, to filter" (Daver, 1993, p. 128). This concept refers to the highest, best or perfect in its original meaning and in current usage. However, this also points to a minority that holds the power, where wealth and privilege are concentrated (Heywood, 2014, p. 116). The known use of this concept in English 
dates back to the early 1800 s when the concept began to refer to social clusters as well during which the concept of "elite" was used by the French industrial and commercial bourgeoisie as a slogan against the aristocracy and the clergy. The slogan "We want the elites" referred to the demand for talented elites that rose from the society to rule France, not the aristocrats or the clergy (Arslan, 2010, p. 6). The widespread use of this concept, which became a slogan for some time, in social and political literature coincided with the 1930s, when sociological elitist theories began to spread, especially with the works of Vilfredo Pareto (Bottomore, 1997, p. 7).

The concept of elite underwent an expansion in terms of its meaning as of the 1930s in a sociological sense, and began to be defined as the minority that controlled the activities related to the fields of society such as economy, religion, politics, art, and military service (Acar \& Demir, 2005, p. 125). In this respect, a non-elite class was foreseen against the elite, and according to this opinion, an elite minority that ruled and an ordinary majority that was ruled existed in all developed or primitive societies; and the governed majority had to obey the decisions taken by the ruling minority. In time, the discussions on the basis of inequality between the ruling minority and the ruled majority, and the studies with the purpose to uncover the roles of the ruling minority in society, were described as Elitism, or Elite Theory, or Elite Theories when its sub-titles were considered (Öztekin, 2003, p. 18-19).

There is the explicit claim that ordinary citizens are incompetent as rulers at the very heart of Elite Theory. According to this theory, the act of ruling must not be founded on self-government by the people, but on a wise and loyal ruling class that has more advanced abilities. This theory claims that every political system consists of two groups, i.e. the ruling minority in the sense of elites or policy practitioners, and the passive mass of the people, namely, the ruled mass. According to this theory, the masses of the people who are governed are ignorant and are not interested in the task of ruling the state, and therefore, they are clearly incapable of ruling. This theory also defines a passive role for the masses as the subjects of political activities only in proportion to the judgment given by rulers (Walker, 1966, p. 286-288).

Elite Theories can be divided into three as "Normative Elite Theory", "Classical Elite Theory", and "Contemporary Elite Theory". Normative Elite Theory is a political theory arguing that the ruling of the elite is desirable in the sense that power must be handed over to a wise or enlightened minority. Classical Elite Theory claims that the rule of society by elites is an inevitable and unchangeable fact of social existence (Yayla, 2003, p. 71-72). Contemporary Elite Theory, on the other hand, argues that the existence of the ruling minority 
is a reality; however, it argues that this is not inconsistent with democracy provided that they are responsible to the ruled mass, and can be dismissed when required (K1şlal1, 2002, p. 333). However, it is worth noting that Contemporary Elitism theorists argue that non-elite people must be given the opportunity to be effective in democratic politics instead of the inevitability of elite rule (Heywood, 2016, p. 259).

It is useful to examine Elite Theories in subsections to express them more understandably and systematically.

\subsection{Normative Elite Theory}

Normative Elite Theory argues that the power must be given to a minority that is superior to the ordinary people, and this must be accepted as a norm. The history of elitism in this sense can be traced back to the Ancient Greek philosopher Plato (427-347 BC), who argued that the king must be a philosopher, and a philosopher must be the king. In addition to Al-Farabi and Ibn Haldun, Friedrich Nietzsche and José Ortega y Gasset can be listed among the thinkers who contributed to elitism normatively after Plato.

Plato, who is considered to be the founder of political philosophy, and who is still one of the greatest names in this respect, placed the ideal state on a class social ground that was divided into three basic business-profession groups, based on the division of labor required by his understanding of the state as producers, protectors, and rulers (Yalçınkaya, 2012, p. 91, 100). According to Plato, producers that constitute the largest and politically lowest class make up the class pursuing wealth and other material elements to cover their physical demands and needs. Producers constitute the social class in which they are allowed to own private property, marry, and live in nuclear family units, and cover the material needs of the state economically. Protectors, which constitute a higher class, were raised to be enthusiastic, courageous, and honor-loving, and make up the segment that obeys the decisions of the rulers until the end. They constitute the bureaucracy of the state which includes the police and the army which are required to control the signs of greed among producers (Tannenbaum \& Schultz, 2011, p. 74-75). According to Plato, protectors emerge from among the people, and the king from the protectors; however, although protectors are an elite group emerging from the people, the king, who is the ruler, is an "only person", who has military virtues and the wisdom acquired during twenty-year education-training, and the authority to rule the people with this equipment (Platon, 1992, p. 47). Plato also argued that ordinary people did not have the virtue of philosophy, and state interests must not be left to them as they would pursue temporary worldly desires (Türkdoğan, 2015, p. 177). Plato also believed that political decisions to be taken by the people would bring disaster, and even 
that it was unnecessary and harmful (Popper, 1998, p. 27). Because, according to Plato, the mind is insufficient in ordinary people, and since these people are governed by the wishes of their body, not by their minds, it would be catastrophic for them to rule the society. Plato also advised that these people must not be allowed to rule even themselves, but must be managed by others (Şenel, 1995, p. 143).

However, Al-Farabi (872-950) considered politics as the mutual construction of a happy living space where the society can live willingly, observing, and developing the common good. In this approach, the socialization of politics and the participation of individuals in political society and life has importance (Bahce, 2008). Al-Farabi argued that individuals who could not meet their needs in this area of life on their own had to cooperate with other individuals. The thinker also argued that as long as individuals fulfilled their duty, they would move towards the goal of achieving "the perfect one" in human nature (Farabi, 2001, p. 79). Like Plato, Al-Farabi also considered it appropriate for individuals to gather under the ruling of one single person and be in an established state order and adopted the Organismic Society Approach (Altıntop, 2016, p. 54) in which a triple social classification method was used in the society like the organs in the body. There is the ruling class at the top of these classes (Akbal, 2017). As it can be understood, Al-Farabi, who put forward an ideal state model that rose above this society by defending the inequality society model, and focused on the ruling class. Al-Farabi considered reality and virtue as the foundation of the state. AlAl-Farabi, who associated the criterion of reality with its being based on revelation, emphasized that there would be no conflicts between the ruler and the ruled with a virtuous and wise ruler (Y1ldiz, 2014, p. 83). Al-Farabi divided the characteristics that a ruler must have into two as those that had to be found by nature and those that had to be acquired later and listed these characteristics in detail (Çubukçu, 1977, p. 25). However, later, considering that too many characteristics cannot be present in one single individual, he accepted that two or three or even more rulers may be at the head of the state to complement each other in terms of these characteristics. In this case, it is seen that Al-Farabi, accepted an elitist form of government in a sense as a kind of "intellectual aristocracy" (Hajayneh, 1987, p. 522).

Unlike normative elitists such as Plato and Nietzsche, the famous Islamic Thinker Ibn Haldun (1332-1406), who is known as the founder of the philosophy of history and the pioneer of sociology, did not agree with the idea that the ruling elite must consist of philosophers (Yaşar, 2016, p. 513). According to him, the ruling elite needs "asabiyyah", which refers to the social ties required for the sustainability of a mutual action to seize and maintain the political power and 
provide the spirit of solidarity (Karadaş, 2018, p. 46). Asabiyyah, which means the ability to act together in the production and social-political relations, may emerge from blood ties, as well as from the unity of religion, language, culture, or tradition (Acar \& Demir, 2005, p. 31). Based on the most famous work of Haldun, Mukaddime, it is possible to reduce the concept of asabiyyah to three basic dimensions the first of which points to a collective struggle from survival to power. Secondly, it expresses social solidarity and integration. The third dimension expresses the feeling that social group members have a common past and the motivation provided by this feeling to the group (Hasanov, 2016, p. 14401441). According to Haldun, asabiyyah is used by a ruling leader and has the characteristics of being a political power. Haldun also claimed that the main purpose of asabiyyah is property, and owning it meant having sovereignty (Haldun, 2014, p. 119). Haldun divided the implementation of policies based on the property into two subclasses the first of which is the disapproved "natural property" in which an autocratic leader is at work governing the people according to their arbitrary wishes. The second is "political property" which is ruling the people in the framework of reason and logic, in which arbitrariness and tyranny are replaced by laws and rules in the subject property. In political property, laws are regulated by smart people, state elders, and people who are skilled in state affairs, and applied to the public. Of course, according to Haldun, who did not approve of property, not every person that has asabiyyah could be a ruler. However, a ruler who can force the people to submit, who collects taxes, who has the power to protect the borders, and who does not recognize any other sovereign power above himself/herself can become a ruler (Karadaş, 2018, p. 46-48).

The German philosopher Nietzsche was another thinker who contributed to elitism by discussing the desire for power. Nietzsche, who evaluated society in terms of two separate classes, defined the first of these two classes as the "people's class", and the other as the "elite class". According to Nietzsche, who argued that religion and daily moral rules were adequate for the people's class, the real mission of this class was to contribute to the preparation of a favorable setting for the formation of an elite class (Nietzsche, 2002, p. 368). Nietzsche, who claimed that the struggle of humankind for survival was essentially a will to power, also argued that all people wanted to have a will for power (Nietzsche, 2002, p. 46). Nietzsche said that the will for power for the weak would be formed by resisting the stronger ones; and for the strong by applying pressure on the weaker, and that this was normal (Nietzsche, 2002, p.321). According to Nietzsche, who also argued that the people must reject their absolute value and approve of the elite ruler as their leader (Nietzsche, 2003, p. 14), the elite person was also the symbol of the will for power (Karadaş, 2018, p. 50). 
Unlike other elitism theorists, Spanish philosopher José Ortega y Gasset (1883-1955) produced elitist theories by making observations on moderate people, which he defined as "mass people", not on elites (Karadaş, 2018, p. 5051). Ortega y Gasset also described the mass man as beings indifferent to their own history, insincere, ruthless, and inflexible (Alvarez-Manilla, 2018, p. 1), who did not think beyond their own welfare. On the other hand, he also argued that there was the adaptation to a higher and superior rule in the structure of an elite or high-qualified person. Ortega y Gasset, who described a highly qualified person as someone from whom much was expected; described the mass man as someone who is not expected to do anything, who is in need of being ruled, who is content with staying as he is. According to Ortega y Gasset, high-qualified people are dynamic and introduce themselves by rising from the masses (Ortega y Gasset, 2010, p. 116-124).

\subsection{Classical Elite Theory}

Classical Elite Theory argues that the ruling class, which holds the power to make decisions, give orders, and demand the realization of these orders in all communities, always consists of a small minority (Kapani, 2012, p. 123). Thinkers such as Gaetano Mosca, Vilfredo Pareto, and Robert Michels can be named among the most important representatives of Classical Elite Theory.

The Italian thinker Mosca (1858-1941) argued that absolute equality did not exist in society at any time, political power was not formed by the will of the majority, and the organized minority always ruled the majority. According to him, all societies, no matter primitive or modern, are divided into two as the ruling class and the ruled class. Even if the former is in the minority in terms of number, it still enjoys all the blessings by constantly holding the monopoly of political power. Although it is always in the majority, the latter class ruled by the minority is under the control of the ruling class, acts in line with the targets, rules, and principles defined by it, and continues its life in this way (Çağla, 2015, p. 97).

According to Mosca, elites are not simply "settle" on the rest of society. On the contrary, they are closely tied to society through state officials, "sub-elite" including the entire new middle class of managers, white-collar workers, scientists, engineers, and intellectuals. Mosca also argued that the stability of any political organism depended on the level of morality, intelligence, and efficacy achieved by this second layer (Bottomore, 1997, p. 12). He also accepted that the elite class was not absolute and unchangeable, and might change in time when faced with pressures from society. This process of change and renewal might occur as a result of a long-term evolution after a social development, or as a result of a sudden social explosion or revolution. No matter which way the change 
occurs, the ruling minority also undergoes some change as a result; however, according to Mosca, another minority comes to the administration as a result of the change, and again, keeps the majority under its control (Öztekin, 2003, p. 20).

Although the first theorist of Classical Elite Theory is considered as Mosca, the Italian sociologist Pareto (1848-1923) is one of its best known theorists (Kışlal1, 2002, p. 330). According to Pareto, people are not natural-born equals, nor can they be equal later. He also argued that not all elites had a say in state administration. According to him, although there were ruling elites in the state administration, there were also non-governmental elites and non-elite people in the administration. In such a case, Pareto handled elites with a triple classification; "Managing elites", "Non-Managing Elites", and "Non-Elite Managers" (Çağla, 2015, p. 97). According to Pareto, displacement and renewal occur between the two layers of society (i.e. elite and non-elite), and individuals go back and forth between these two layers. Pareto named this as "the circulation of elites" (Arslan, 2007, p. 8). According to Pareto, if the elites succeed in integrating successful individuals coming from the lower layers of society, the circulation of elites continues. If elites fail in integrating these individuals coming from lower layers, the power struggle becomes harder, and the change of elites becomes inevitable. Pareto described this as a "revolution" (Kışlal1, 2002, p. 330).

Pareto discussed the political elites in two separate groups as "Foxes" and "Lions". Although foxes prefer to rule with cooperation, intrigues, and cheating, lions rule by using power; and although foxes are decentralized, pluralistic, argumentative, and are reluctant to use power, lions are more conservative and are in favor of unity, uniformity, loyalty, and centralism (Drochon, 2020, p. 12). According to Pareto, foxes and lions can function in any model of government. The attitudes of foxes and lions are not affected or shaped by the governing body (Delican, 2012, p. 325). Pareto attaches importance to feeding the ruling class with those coming from the non-ruling class both in terms of quantity and quality. Because, according to Pareto, the interruption of the circulation of the elites might deteriorate the current balance in the society and prepare the collapse of the ruling class (Çağla, 2015, p. 98). For this reason, Parato also argued that elites like Mosca must be open to change. Because, as Mosca also argued, social explosions are always possible if elite groups are closed to the demands of the subgroups to participate in the administration. As a result of such explosions, the change, which is not accepted by the elite group voluntarily, occurs through force, and another elite group takes its place (Pareto, 1935, p. 1430).

Another classical elite theorist was the German sociologist Michels (1876-1936). According to Michels, who argued that elites would inevitably exist 
in all societies, the ruling class consisted of a very limited number of members. According to him, the ruling group emerging in every society and organization had the tendency to form an oligarchy gradually, and such a minority group would try to consolidate and perpetuate its authority after mastering the decision-making processes; and finally, it will prioritize its own interests by moving away from its social base and the mass it emerged from (Kışlal1, 2002, p. 331-332). The theory of Michels based on these motives was formulated as "The Bronze Law of Oligarchy". According to Michels, there is a contradiction between the ideal government system of democracy, self-ruling of the masses, and actual reality. In all democracies, a de facto oligarchic ruling class forms, and the mass falls under the rule of this ruling minority. According to Michels, this also applies to organizations e.g. political parties and trade unions (Vergin, 2012, p. 127-128). According to him, this occurs mostly because of the nature of complex social systems. Because of the growth of organizations and the complexity and hierarchy that stem from this growth, the authorities will inevitably be concentrated in the hands of a small group at the top of the organization. In other words, oligarchy is a characteristic that stems from the inner working of bureaucracies or large-scale organizations. Modern people cannot establish and maintain such institutions after being faced with a vicious circle without effectively transferring power to a small number of managers at the top of such organizations (Lipset, 2008, p. 14; Demirci \& Önder, 2016, p. 577-578).

\subsection{Contemporary Elite Theory}

Unlike what classical democracy theorists claim, Contemporary Elite Theory argues that democracy is not a way of life, but is a form of government ensuring that elite rulers who dominate the decision-making processes are elected at regular intervals (Acar \& Demir, 2005, p. 88). Contemporary Elitism, which is also known as "pluralist", "competitive", or "democratic", argues that contemporary elites are fragmented along various lines instead of coherent and unified integrity (Yayla, 2003, p. 72). According to Contemporary Elitism, which tries to associate the concept of the elite with democracy (Karadaş, 2018, p. 5960 ), political power focused in one single center or in the hands of an elite group, creates dangers such as oppression-tyranny, despotism-tyranny, and political pollution. For this reason, elites must be independent of each other and from the state. Also, the political elites who are in power must be controlled and balanced by other elite groups that have a share in the power. This approach is in favor of "equal opportunities in reaching a strong position", and does not favor the principle of "equal distribution of power among the segments of the society" of the theory of democracy (Arslan, 2007, p. 34-35). In addition, according to the advocates of this theory, the classical definition of democracy favoring 
"government of the people by the people for the people" is not compatible with current political reality. Because the government cannot be in the hands of the people, or even in the hands of the majority in democracies. Contemporary Elite Theory claims that the role of the people is to elect leaders to govern them, and to bring the minority who will take and implement political decisions to power with their own votes even in democratic regimes (Kapani, 2012, p. 132). There are thinkers such as Harold D. Laswell, Raymond Aron, and C. Wright Mills Among the important representatives of Contemporary Elite Theory.

The American political scientist Harold D. Laswell (1902-1978) argued that political elites are the class or group holding the political power in all societies. According to Laswell, political elites are always necessary for the harmonious management of society. The political elite rules the society with the responsibility of an orchestra conductor to ensure harmony within the society. $\mathrm{He}$ also argued that a society can be a democratic society even if it is ruled by an elite minority. The important thing is that the administrators have a responsibility towards the ruled mass and they do not object to leaving their position if the governed mass desires (Kışlal1, 2002, p. 333-334). For Laswell, the condition for the minority that holds the political power to be considered democratic is that they come to power with the free will of the society after a free, equal, and secret election, and they can be controlled by the ruled majority (Öztekin, 2003, p. 22).

The French sociologist and philosopher Raymond Aron (1905-1983) also argued that all regimes are always ruled by a minority, and in this sense, all regimes have an oligarchic structure. According to Aron, an elite minority always rules large masses no matter whether it is a Western liberal democracy or a communist regime. The rulers are elites in both regimes. However, Aron also argued that although there is a single and unified elite in communist regimes, elite groups are numerous and divided into Western liberal regimes (Kapani, 2012, p. 135). One of the important factors Aron emphasized is elite unity and solidarity. The boundaries and balance of this unity and solidarity have great importance for democratic regimes because the general unity and solidarity of the elites is extremely important for independence. However, the fact that the elites are in full disorganization and fragmentation brings the end of the state. The thinker also points out that there is a general consensus among the democratic elites on basic social issues, although there are significant differences in many other areas (Arslan, 2007, p. 41).

The American sociologist C. Wright Mills (1916-1962) analyzed the elites in power in the case of the USA. Mills said that the USA is governed by people who hold dominant positions in the political, military, and economic areas. The thinker also said that these three fields are interlocked with each other, 
arguing that prominent figures in these three power fields -arms dealers, corporate executives, and political leaders- tend to come together to form the power elite of the United States (Wallace and Wolf, 2012, p. 161-162). Mills also argued that these elite people, who had the capacity to affect the lives of ordinary people, were similar to each other in terms of their origins, cultures, and lifestyles, and there was a common interest among them. For this reason, he also argued that the contradictions among themselves would not affect their common interests in general (Kışlalı, 2002, p. 335-336). For this reason, these groups might form become homogeneous. On the other hand, the governed masses gradually lose their ability to have a say in political decisions as they are divided, passive, and without power. However, according to Mills, it is not possible to claim that the ruling elite is subject to real control by the people (Kapani, 2012, p. 137).

\section{ELITE}

\section{ADNAN MENDERES AS AN ECONOMIC AND POLITICAL}

\subsection{The Life of Adnan Menderes before Politics (1899-1930)}

With his full name, Ali Adnan Menderes (Aydemir, 2004: 12) was born in 1899 in a mansion of his uncle Sadık Bey in Sarayiçi of the city of Aydın (Dilipak, 1990, p. 19). The formal education life of Menderes started in the Junior Izmir Ittihat and Terakki High School. However, it is known that Menderes did not finish this school, and was transferred to the American College in Izmir Kızılçullu (Kısakurek, 1998, p. 164; Ağaoğlu, 2016, p. 37). Menderes could not graduate from the American College, and when he was studying at this school, he became a soldier in 1916 because of the First World War (Inan, 2002, p. 9). Menderes, who served as a second lieutenant in the $17^{\text {th }}$ Army Corps in Izmir, became ill with poisonous malaria on his way to the front. After treatment, Menderes was sent back to Izmir (Aydemir, 2004, p. 37-38). Shortly after Menderes returned to Izmir, the Armistice of Mudros was signed and the war ended. In this way, the experience of the First World War, in which Menderes did not actually engage in and mostly stayed behind the front, came to an end, and Menderes was demobilized (Inan, 2002, p. 11).

After his demobilization, Menderes returned to the farm he inherited from his grandfather, Hac1 Ali Pasha, established an armed resistance organization, which they called the "Ay-Yıldiz Gang" (Crescent-Star Gang), with a group of friends, when the Greek occupation began to spread in the Aegean Region (Aydemir, 2004, p. 53), and started to fight voluntarily. The CrescentStar Gang, which participated in some fights in the region, later joined the regular army. Menderes joined the regular army in October 1920 and served as a cavalry platoon commander and an officer of the Military Service. Menderes, who was 
then given the command of the $12^{\text {th }}$ Division, was discharged on 1 August 1923. Menderes, who also took part in the Great Offensive, fought for nearly three years and did not receive any injuries (Inan, 2002, p. 12-13). Menderes was awarded the Medal of Independence for his struggles (Aydemir, 2004, p. 54). Menderes, who returned to the farm after being demobilized and started to grow cotton, married Fatma Berrin Hanım, who was a member of the Evliyazadeler family, one of the well-known families of Izmir, in 1928 (Menderes \& Akyol, 2011, p. $163)$.

\subsection{Political Life of Adnan Menderes (1930-1960)}

The political life of Menderes began in 1930 when he had just established Free Republican Party (FRP) and became the head of the Aydin organization. Menderes contributed to the establishment of FRP organizations at significant levels not only in Aydın, but also in Denizli, Nazilli, Muğla, and its surroundings. However, when FRP dissolved on November 17, 1930, the party chairmanship of Menderes in Aydın ended (Güneş \& Akdağ, 2013, p. 188). After the dissolution of FRP, Menderes joined the Republican People's Party with the influence of Mustafa Kemal Atatürk (Menderes and Akyol, 2011, p. 155-156), and was elected as the deputy from Aydın in 1931. Menderes decided to complete his education after he became a deputy and enrolled in Ankara University Faculty of Law in 1932 (Aydemir, 2004, p. 94-96). Menderes graduated from the Faculty of Law in 1935, and worked as the party inspector and parliamentary committee member in the party, especially in the western parts of the country until 1940 (Ünlü, 2020, p. 58).

However, in time, it is seen that Menderes started to contradict the party administration. The oppositional attitudes of Menderes during the negotiations about the Draft Law on Providing Lands to Farmers, which was presented to the parliament by the Republican People's Party (CHP) in 1945, initiated the process that would result in his leaving the party (Çufal1, 2004, p. 40; Demir, 2009, p. 28). The Draft Law on Providing Lands to Farmers, which aimed to eliminate large land properties cultivated by landless shared-farmers and farmers in the framework of landlord-worker relations, was brought to the agenda of the Parliament in May (Inan, 2002, p. 52-53). The political elitist aspect of Menderes was detected during the negotiations on this bill. Two different groups emerged during the debates on the law in the parliament. The first group was the intellectuals and civil servants who supported the land reform by emphasizing its social justice dimension. The second group was the large-scale landowners who opposed the bill by arguing that the land should not be divided and the existing system should be preserved arguing that this law violated the private property right given to citizens by the constitution (Demir, 2009, p. 30). Menderes, who 
was also one of the owners of large lands, showed his elitist side by being in the second group against the bill. Menderes also opposed the establishment of a large number of small businesses that were envisaged by the bill. On the contrary, he favored the establishment of larger enterprises by combining small businesses and defended large farms and landowners in this sense (Aydemir, 2004, p. 117).

As a matter of fact, the debates on the Draft Law on Landing the Farmers, which was prepared to distribute lands to farmers with no or little land, in the Parliament during the budget negotiations ignited the fuse of the transition to a multi-party system in Turkey (Altaş, 2011, p. 21).

The Draft Law on Providing Lands to Farmers, whose voting Menderes did not participate in, and which was seldom applied except for the granting of some treasury lands to landless peasants, passed with a majority of votes on 11 June 1945 and was enacted. The negotiations on the draft law brought the opposition in the CHP to the surface. The first organized action of the intra-party opposition was on 7 June 1945 when Menderes and the deputies acting with him, Celal Bayar, Refik Koraltan, and Fuat Köprülü, submitted a draft to the CHP Group demanding the full application of the constitution and the establishment of democracy. This draft, which was also known as the "Quatro Report" because the number of the deputies who signed it was four, aimed at reforming the CHP rather than establishing an opposition party (Timur, 2003, p. 17-18). However, despite this, the draft in question became the initial symbol of the organized political opposition (Zürcher, 2000, p. 306).

At a time when the war ended and society became ready for democracy, The Memorandum of the Four (Altaş, 2011, p. 30), which mentioned issues such as "it is necessary to control the government by the National Assembly, recognize the rights and freedoms in the constitution, end the one-party regime, and change the program and statute of the CHP for these demands" took the CHP by storm. Finally, it was refused after seven hours of uninterrupted negotiations (Bayar, 2010, p. 44-45).

However, the criticisms brought against the CHP in the draft were received positively by the public, and the proponents of this draft were encouraged and began to write articles that criticized the government, the prime minister, and anti-democratic laws in the opposition newspapers at that time. Although the party administration asked for an explanation from these deputies for these critical articles, no satisfactory answers were received. In this way, the CHP administration decided to expel Menderes and Köprülü from the party in September 1945 arguing that they acted against the spirit of the party. Later, Koraltan, who criticized this decision, was also expelled from the party (Karpat, 2010 , p. 233-234). Bayar, who was the last of the signatories of the Quatro 
Report, resigned from his party in December of the same year (Zürcher, 2000, p. 307).

Then, the Democrat Party (DP) was founded under the presidency of Bayar on January 7, 1946 (Akşin, 2007, p. 276). The establishment of the DP was welcomed with enthusiasm, and the program of the party aroused the interests of the people who were dissatisfied with the policies of the single-party rule (Başgil, 2014, p. 53-55). However, as all of the founders of this party were former CHP members, very limited differences were identified between the statute and program of the party and those of the CHP (Ahmad, 2010, p. 30-31). Özbudun (2010, p. 24) argued that the negligible and small differences between these two parties emerged in the definition of the role of the state, bureaucracy, private enterprise, and local initiatives. However, the establishment of the DP affected the policies of the CHP, and the attempts of the CHP towards democratization were accelerated. Therefore, the single-party regime, which brought a series of reforms to the agenda, announced that it would switch to a single-stage election system for the first time in the history of Turkey, and announced that the authority to close newspapers would be taken from the government and given to the courts. The government, which promised that the autonomy of the universities would also be recognized, abolished the Agricultural Products Tax to gain the support of the peasants and workers. The position of Inönü was abolished as the immutable chairman in the same period, and it was accepted that parties and syndicates based on class could be established (Akşin, 2007, p. 276).

After all these reforms, the general and local elections, both of which were normally supposed to be held in 1947, were held in 1946, for the purpose of not allowing the DP to gain public support (Timur, 2003, p. 70). General elections were held on 21 July 1946, after the local elections that were held on 26 May 1946, which turned into a de facto single-party election because it was boycotted by the DP (Inan, 2002, p. 124). In these general elections held at one level and without the control of legal bodies, the votes were cast openly but were counted secretly (Timur, 2003, p. 71). The DP, which was able to nominate only 273 candidates for 465 deputies in the election, was able to have 66 deputies. Menderes could not be elected from Aydın, from where he was nominated a candidate, but he still entered the parliament as a deputy from Kütahya as he was nominated from Kütahya (Birand et al., 2016, p. 40).

The First Congress of the DP was convened on the first anniversary of the party on January 7, 1947 (Çufalı, 2004, p. 94). Bayar was re-elected as the chairman in this congress after he received 541 votes from 548 delegates, and Menderes was elected as a member of the central administrative board (Inan, 
2002, p. 189-190). Menderes organized a series of rallies After this congress, mostly in the Aegean Region, and talked about the pressure exerted on them by the ruling party, which attracted great attention from the public, and emphasized the "freedom" concept. Bayar was re-elected as the chairman in the Great Congress II of the DP, and Menderes became one of the fifteen people who were elected to the General Administrative Board of the party (Demir, 2009, p. 128129).

In this process, tensions emerged between the government and the opposition regarding many issues, especially the "rigged polls". Inonu had a declaration called "the 12 July Declaration" prepared to end this tension and normalize politics, which was later accepted between CHP and DP. However, this declaration caused deep cracks in both parties, and caused resignations (Bayar, 2010, p. 110; Demir, 2010, p. 161-177). Then, the Recep Peker Government resigned, and was replaced by the Hasan Saka Government. After the resignation of the Saka Government, the Semseddin Gunaltay Government was established (Demir, 2010, p. 180-186) during which the Law on Parliamentary Elections No. 5545 was enacted providing opportunities such as "secret ballot, open counting", "all kinds of judicial guarantees to elections", and "propaganda for opposition parties on the radio" (Seyhanlioglu, 2011, p. 188189). After this law was enacted, preparations for the 1950 elections were initiated.

\subsubsection{Political Rise of Adnan Menderes}

May 14, 1950 was the date when Pareto's Theory of the Circulation of Elites was tested for Turkey. The founding elites of the Republic had to go to elections by responding to the demands for change On this date, and as a result of the elections, they left their place to the new elites as rulers. The political power changed through democratic elections On May 14, 1950, for the first time in Turkey (Lewis, 1993, p. 303). The DP received 53\% of the votes in these elections, mostly from rural areas, with 408 deputies; and the CHP took $40 \%$ of the votes and had 69 deputies. In this way, the twenty-seven-year single-party rule came to an end (Aydemir, 2011a, p. 492; Aydemir, 2011b, p. 32-33).

The social characteristics of the new ruling elites also differed when compared to the single-party period. The MPs of DP were younger on average, and had lower university education levels; however, the rate of having commercial and legal backgrounds was higher. Another difference was that there were almost no deputies who had bureaucratic or military backgrounds (Zürcher, 2000 , p. 321). However, it is debatable whether this difference level was really significant. Mert (2007, p. 20-22) argued that Menderes and other DP elites, who represented the beliefs, values, and lifestyles of the conservative segment, who 
objected to the Western-based transformation of the single-party government, and who moved these objections to the political arena, were not different from the CHP members in terms of elitism. The author argued that this was a justification that they considered it a mission to introduce democratic politics beyond the oneparty line to a society that was not yet at peace with the democracy concept.

On the other hand, the differences between the two parties also seemed unclear, especially in terms of the policies produced for democratization. The understanding of democracy of DP and Menderes, who ensured party unity by keeping their ranks firm against the CHP, was at a level where the approval of the people provided them with an unlimited power area, and opposition to the DP was considered equal to betrayal (Özbudun, 2010, p. 25). In this sense, the main difference between this party that considered democracy as a number regime and CHP was that although the first one received support from rural areas, the latter received support from cities (Ahmad, 2010: 68). Also, the main objection of this party to the CHP was not based on the authoritarianism of the CHP, but on the basis of its "alienation from society" (Mert, 2007, p. 101).

The DP Parliamentary Group convened on 20 May after the 1950 elections, and decided to nominate Bayar for the Presidency. The DP candidate Bayar became the President with 387 votes out of 453 in the Presidential Election that was held in the Grand National Assembly of Turkey (TBMM) on May 22, Koraltan was elected as the Speaker of the Grand National Assembly of Turkey. President Bayar assigned Menderes to form the government (Demir, 2009, p. 146). He formed his cabinet on May 22, 1950, and held the first group meeting on May 28, 1950. Menderes, who declared the government program in the Grand National Assembly of Turkey on 29 May 1950, defined the 14 May elections as the most important revolution in the country until that time and said that they came to power as a result of the full and free manifestation of the national will for the first time in history (Aydemir, 2011b, p. 39).

As of his first days in power, Menderes, who was understood to consider himself and his party as the only representative of the national will, took important decisions such as joining the war without consulting the opposition. The decision to join the Korean War, which was taken only two months after the DP came to power, was taken without even consulting the parliament and the opposition (Aydemir, 2004, p. 292). On the other hand, Menderes was quick to use the anti-communism weapon, which was processed throughout the history of the Republic and which would later be used by center-right politicians with the influence of the religious and conservative base he had. He did not avoid applying harsh legal measures to strangle the intellectual life of the country (Eroğul, 1990, p. 61). 
Menderes also tried to apply pressure on the opposition party CHP During this period. In this respect, the Rural Institutes, which were the eyes and ears for the CHP, were abolished on the grounds that communist propaganda was made in them in rural areas, and their curricula were not suitable for training qualified teachers (Seyhanlioglu, 2011, p. 179).

All the properties of the Community Centers and some of the properties held by the CHP were transferred to the treasury with a unanimous decision in the DP group (Bakan \& Özdemir, 2013, p. 385). The DP government also took action to cease the support of the CHP in university circles in addition to transferring its assets to the treasury. Despite the public support of the DP, the fact that the CHP had more intense support in academic circles and many professors had served in the CHP disturbed Menderes. Menderes prepared a bill prohibiting professors from dealing with politics and had it enacted on 21 July 1953 to deprive the opposition of this support (Eroğul, 1990, p. 77).

The CHP was not the only addressee of the repressive acts of the DP. The politicians who left the DP and founded the Nation Party (MP) when they were still in opposition were also affected by these pressures. The DP, which used the fact that forty MPs left the party after claiming that the party was working against Atatürk and his revolutions in the congress in June 1953, had the MP closed on July 8, 1953, on the grounds that it was against Atatürk and his revolutions (Eroğul, 1990, p. 79). The Menderes Government did not tolerate criticisms coming from the press apart from its political rivals towards the 1954 elections and enacted a law that brought heavy penalties to the press. According to this law, journalists who were brought to court were also deprived of the right to prove their claims. The efforts of nineteen DP deputies, who opposed this law and defended the right of proof of the press, were fruitless after it was made fun of by Menderes, and these deputies left the DP or were dismissed (Akşin, 2007, p. 283).

The popular support of the DP did not decrease Despite all its repressive rule before the 1954 elections, on the contrary, it continued to increase. The improvement of the economic policies of the party, even if relatively, can be named as a reason for this. Although its approach to the economy was random and lacked a comprehensive plan, there was a significant increase in the welfare of the rural areas, especially in the early periods of the DP rule. There was a high interest at that time in agricultural products and mines from Europe, which was just emerging from the difficulties that were caused by the war. The DP government, which made use of this situation well, focused on the production of such products and prepared an infrastructure to facilitate their export. Asphalt roads that could carry all vehicles were built with the financial and technical assistance of the USA, which led to the increase of transportation companies and 
the foundation of the automobile industry. The rapid proliferating of asphalt roads also triggered the opening of coastlines and beaches to domestic tourism and then to foreign tourism, which brought about significant consequences for the entire society (Ahmad, 1995, p. 164).

The fact that he increased his votes in the 1954 elections, and his authoritarian policies were approved in one sense, made Menderes maintain his stance by not considering it necessary to take anything into account other than his own electorate. The things he said in the interview right after the elections to journalist Ahmet Emin Yalman, who was the supporter of his own party revealed the understanding of democracy of Menderes, who saw himself as the only determinant and was considered a clue for the policies he would follow in the next period. In this interview, Menderes said "Elections showed how many of our citizens adopted the path we follow. I was consulting with you journalists about this until now. But this great public confidence shows that such a consultation is no longer necessary" (Ahmad, 1995, p. 160).

As a matter of fact, after the establishment of the Menderes Government on May 26, 1954, the cities that voted for the opposition were punished as the first step. In this context, Adiyaman was separated from Malatya, which was one of the three cities where CHP had the majority, and thus Malatya was divided into two. Kursehir, where the Republican Nation Party (CMP) had the majority, was reduced to district status, and was attached to Nevsehir. The new government also took serious measures regarding the bureaucracy at the beginning of this period. The minimum period of service that was needed for the retirement of civil servants was reduced from 30 years to 25 , and the appeal against the retirement decision was closed. All public officials were then placed under the order of the organization they worked, and the way was opened for their dismissal with another law that was enacted after this. The opportunity of judicial reviews against all these proceedings was also kept closed. It was also seen that Menderes did not hesitate to take steps to consolidate his position in the party after the elections (Tuncay, 2000, p. 172-181).

The absolute dominance of Menderes in the party after the 1954 elections seemed in line with the assumption of Michels that every political organization would eventually surrender to the bureaucratic oligarchy. The fact that the party organization expanded at considerable levels made it difficult to control it and led the organization to degenerate. For the same reason, objections to the authority of Menderes started to increase right after this election. Menderes expelled some deputies who opposed him from the party on 13 August 1954. However, the unrest in the party did not end and was carried to the next year. In this process, the attitudes of Menderes towards the criticisms of his own party members were 
in line with the lion-fox metaphor of Pareto. Menderes, who aimed to soothe some of the deputies by convincing and using his authority, appeased Mükerrem Sarol by using his old friendship, Fuat Köprülü by talking, Fevzi Lütfü Karaosmanoğlu and Fethi Çelikbaş by not including them in the General Administrative Board (GAB) meetings as they were against the party and created a dichotomy, and referring Feridun Ergin to the High Court of Honor, and calmed the opposition in the party, at least for some time (Bozdağ, 1975, p. 50-51).

Menderes was re-elected as the chairman in the $4^{\text {th }}$ Great Congress convened on October 15, 1955. The fact that Köprülü, who was known to have disagreements with Menderes, received the highest vote after Menderes in the Congress, showed that the intra-party opposition to Menderes continued. Although CHP and Republican Nation Party (CMP) did not participate in the municipal elections held on 13 November 1955 In the same period, the DP lost votes (Apuhan, 2007, p. 119).

This loss of votes increased the unrest in the party and led to harsh discussions at the party group meeting that was held on 29 November 1955 in which harsh criticisms were made against Menderes, and it was stated that the main issue of the party was the "Prime Minister". As a result of these criticisms, firstly the Minister of Economy and Trade, Sitk1 Yırcalı (Burçak, 1998, p. 358), then the Minister of Finance Hasan Polatkan, and the Minister of Foreign Affairs Fatin Rüştü Zorlu resigned (Eroğul, 1990, p. 115). Menderes, who spoke to respond to criticisms, talked about the success of his party; however, when he could not convince his group, he changed tactics, and said that there might be some mistakes, the group should not deal with these issues, and he was ready for the orders of his group under all circumstances. Menderes, who spoke again after the criticisms continued, invited those whose names were involved in this incident to resign and left the hall (Burçak, 1998, p. 360-361). Menderes spoke again with the strange formula put forward by the Minister of State Sarol to end the crisis (Eroğul, 1990, p. 115), and demanded a vote of confidence from the deputies, not for his cabinet, but for himself as the prime minister, arguing that he left himself entirely to the discretion of the group. The party group responded positively to this request and demanded that the cabinet be dismissed, except for the prime minister. In this way, oddly enough, Menderes remained prime minister but the government was dismissed (Birand et al., 2016, p. 113-114).

\subsubsection{Political Decline Period of Adnan Menderes}

The fact that Menderes remained prime minister did not prevent his political career from decline. One of the reasons for this was the economic bottleneck. Inflation had reached $18 \%$ Since 1956, but growth rates remained at $4 \%$. The artificially high value of the Turkish lira against the US dollar caused 
the foreign exchange accumulation to melt down. Similarly, the application of incentives to the export of agricultural products to form a competitive opportunity in the world market led to the idleness of agricultural machinery (Ahmad, 1995, p. 165-166). Under these conditions, the Menderes Government enacted the National Protection Law on 18 May 1956, which allowed to regulate the economy including the distribution of goods and services and determining their prices to overcome the economic bottleneck (Ahmad, 1995, p. 166). However, such measures of the government did not help overcome this condition and made the situation even worse. For this reason, Menderes had to approve the stabilization package envisaged by the IMF in 1957. However, because of the negative consequences of this, Menderes went to early elections in order not to lose votes, and held the elections, which should have been held in 1958, to October 1957 (Demir, 2009, p. 331). The DP enacted laws Before the elections to prevent the de facto unification of the opposition parties (Eroğul, 1990, p. 125).

The effects of the economic bottleneck were observed in the 27 October 1957 elections. The DP's vote, which was $58.42 \%$ in previous elections, decreased to $47.90 \%$, and the number of deputies decreased from 503 to 424 , after which the ruling party abolished the obligation of the ministers to answer questions from the opposition on 27 December 1957, and accepted that the desired part of the speeches of the opposition party members could be removed from the minutes. The right of the President of the Assembly to remove a deputy from the Assembly was increased to twelve from three (Aydemir, 2000, p. 262).

Menderes went on a Far East tour on April 24, 1958, which covered Japan, Taiwan, South Korea, and India, and targeted to develop commercial relations with these countries to find a solution to the growing economic bottleneck; however, he could not establish the commercial connections he desired (Eroğul, 1990, p. 141). The DP government, which increased the prices of many basic goods in June 1958, had to go into devaluation in August, and as a result, the value of the Turkish Lira against the American Dollar was reduced more than three-fold (Özdemir, 2013, p. 29). Because of arbitrary practices such as irregularities in the economy management, tender corruption, and partisanship in this period, investments stopped and the business world, which had supported the DP from the beginning, ceased its support (Aydemir, 2000, p. 274).

There were developments During this period outside the country that made Menderes uneasy. A coup occurred by the Iraqi army and King Faisal and Prime Minister Nuri Said were killed by the revolutionaries on 14 July 1958. A republic was declared in Iraq right after this revolution, which received support from the public. This event left deep traces on the domestic and foreign policy of Turkey. The personal impact of this coup on Menderes was greater. Menderes 
attempted to engage in a military intervention against the new administration in Iraq and, according to İnönü, gave up this only with the pressure of the United States (Eroğul, 1990, p. 142). Menderes, who frequently talked about the revolution in his speeches after this incident, could not eliminate the thought that a coup would be plotted against him (Eroğul, 1990, p. 144; Aydemir, 2000, p. 277; Apuhan, 2007, p. 136).

Menderes made attempts to keep the people who voted for him on alert in this period with a move that caused the impression that he hoped it would be functional in case there would be a revolution. For this purpose, Menderes gave the "Homeland Front" speech at the meeting held in Manisa on October 12, 1958. Menderes said to this formation, which considered the opposition to be against the Homeland Front, and therefore an enemy, "My dear citizens, we will unite in the Homeland Front and preserve our works together" (Cumhuriyet Newspaper, 13.10.1958, cited by Konca, 2011, p. 62-63). After the establishment of the Vatan Front, the names of those who joined this formation were announced on the radio every day, and Menderes thanked these people (Aydemir, 2000, p. 362).

An unexpected development took place in this process. The plane with the name "Sev", which was carrying a delegation of twenty-seven people, including Menderes, to attend the Trilateral Cyprus Conference to be held in London between the United Kingdom, Greece, and Turkey, crashed near London on 17 February 1959. In the accident in which sixteen people lost their lives, Menderes survived with injuries. Menderes, who was hospitalized by the employees of a nearby farm, was discharged on February 23, 1959 after being treated at the London Clinic hospital for some time, and returned to the country on February 26, 1959 (Yalçın, 2004, p. 494-496). The plane crash not only increased the popularity of Menderes again, but also paved the way for a peaceful atmosphere in the political atmosphere of the country. İnönü was among those who greeted Menderes on his arrival from Istanbul to Ankara, and he shook hands with Menderes (Eroğul, 1990, p. 147).

After less than two months of peace, the political tension continued. A conflict broke out between CHP supporters and DP supporters on April 29, 1959, when İnönü entered the region where he personally fought as an officer during the War of Independence in Uşak, where the propaganda campaign that the CHP called as "Great Offensive" started. İnönü, who came to the train station to leave the city because of these incidents, was actually attacked there. The police did not intervene, and the members of the army protected İnönü. The fact that the DP government did not initiate an effective investigation regarding these incidents received reactions and made the members of the army uneasy. Also, the fact that the actual attack on the opposition party was not investigated by the government 
caused the perception that these events were approved by the government, and made it easier for İnönü to be attacked in other places later. İnönü, who went to Istanbul on May 4, 1959, was attacked again when he came to Topkapı by car. A then-non-commissioned major, who happened to be in the area accidentally, intervened against the attackers, whom the police did not intervene, and organized the soldiers in the area taking İnönü out of the area. The government, which did not initiate an effective investigation against these attackers who were brought from other districts and turned out to be an organized community later in the Yassiada trials (Aydemir, 2000, p. 285), enacted a broadcast ban on the incident (Aydemir, 2011b, p. 372-375).

In the early 1960 s, political tension continued to increase with the mutual harsh statements of Menderes and Inonu. Broadcasts began to be made on the Turkish Radio Television (TRT) radio at the end of March, which worked like the propaganda bulletin of the DP, arguing that "CHP had lost its legitimacy and had become the focus of conspiracy, carrying the flag of a coup" (Demir, 2009, p. 372-373). The DP Parliamentary Group decided to open a parliamentary investigation on the CHP on April 12, 1960, and then to establish a commission consisting of 15 people on April 18 to investigate the allegations that the CHP had established a "cell organization" to come to power through illegal ways, bore arms, and was preparing for a rebellion (Eroğul, 1990, p. 156). The decisions of this Commission were final, and no higher authority was foreseen against the Commission's decisions. The commission was equipped with many extraordinary powers such as censoring all publications, banning all kinds of meetings, and political actions (Kongar, 2006, p. 154). After the Investigation Commission that had extraordinary powers was accepted, a mass student march took place in Istanbul on April 28, 1960. The demonstration in which slogans such as "Menderes resign" were shouted, a student was killed by the police and the university rector was dragged (Aydemir, 2004, p. 361), was suppressed violently. Then, measures such as martial law, curfew, and broadcast ban were taken. Another student march took place in Ankara On April 29. In his speech on the radio the same day Menderes said, "They will not delay in understanding what it means to be against the order and the state". He showed that he was determined to suppress the demonstrations violently (Eroğul, 1990, p. 157-158).

With the protesting march of the Military Academy students and officers on May 21, 1960, a military revolution was considered as a matter of time. The DP Group convened on May 25, 1960, and a deputy, who said "A coup is coming", demanded the resignation of Menderes and the cabinet (Apuhan, 2007, p. 154). Menderes, who responded to this suggestion by saying "I regret it", promised that he would rectify the situation, moved to Eskişehir the same day 
despite the warnings of the party members asking him to stay in Ankara and do something (Aydemir, 2004, p. 409-411). Menderes, who received the news that the army seized power on the night of May 26, 1960, went to Kütahya by road and was arrested there (Eroğul, 1990, p. 161). He was taken to Yassiada after the coup. In the court that was established by the National Unity Committee in Yassiada, he was put on trial on October 10, 1960, with some allegations such as his extra-marital affairs, and the fact that he had paid some members of the press out of the Black Budget in return for their support to him and the women with whom he had intercourse, and due to "Violation of the Constitution, the establishment of the Homeland Front, the establishment of the Investigation Commission, 6-7 September incidents, corruption, crimes against demonstrators in Istanbul and Ankara, irregularities in Black Budget, assault to opposition leader in Topkap1 and Kayseri". The court that ended on September 15, 1961 sentenced Prime Minister Menderes to death together with Minister of Finance Polatkan, and Minister of Foreign Affairs Zorlu (Apuhan, 2004, p. 223). Bayar escaped the capital punishment because of the age limit, and MPs of the DP were sentenced to life imprisonment and other severe punishments (Seyhanlioglu, 2011, p. 224).

\section{CONCLUSION}

In the present study, Adnan Menderes, who represents the milestone of center-right politics in Turkey, is discussed from the perspective of Elite Theory. Menderes, who was born in a mansion as the son of an elite family, the owner of large lands in most of Aydin, started life as an elite in terms of his wealth. Menderes, who stepped into the political elite position after being elected as a deputy in 1931, was in politics for the CHP for fourteen years. He left the CHP and founded the DP with a group of his friends in 1945. Menderes, who became the leader and prime minister of the DP, which came to power in the 1950 elections, acquired the position of the ruling elite. Menderes, especially in the last years of his ten-year rule, was overthrown as a result of a military coup on May 27, 1960, and was then executed on September 17, 1961 with a forced change that he did not voluntarily accept as a ruling elite.

The professional life of Menderes began in 1923 when he was discharged after the War of Independence, and he became the head of the Çakırbeyli Farm, which was inherited from his grandfather. Menderes, who became one of the remarkable people of Aydin with the success he achieved here, and who consolidated his elite position with wealth at a very young age, was engaged in farm business until 1930, the date when he became the Aydin Provincial President of FRP. Menderes, who was elected as a Member of Parliament from the CHP in 1931 after his short-term FRP adventure, remained in this party until 1945 when 
he resigned, and maintained his position as a political elite. Menderes, who continued his political career in the DP as of 1946, became the ruling elite after 1950 .

The fact that Menderes tried to sustain his power by applying repressive policies, especially towards the end of his power period, seems to be suitable for the arbitrary administration, which Ibn Haldun described as "natural property". Also, it was revealed in the Yassiada trials of Menderes that he had extramarital affairs and his actions such as the fact that he provided financial aids to some members of the press in return for their support regarding his affairs with women, shows that he lacked the virtues that Al-Farabi defined as "moral characteristics" and which he claimed were a characteristic that should be sought in a ruler. On the other hand, Menderes used violence against the student protests and CHP opposition when he was liquidating the opposition sometimes by persuading and sometimes by cheating when he was in power. Also, Menderes tried to solve the unrest in his party by applying the method that Pareto conceptualized as "fox" and "lion", sometimes by using cunning and deceit, and sometimes by using brute force. He tried to keep some of his opponents in the party by giving them office, or he expelled others from his party.

The refusal of Menderes to accept change even when the possibility of a military coup became more apparent, and as a result of this, his having to leave his post due to a military coup, seem appropriate to the assumption of Mosca and Pareto who argued that "if the elites do not accept change, this change will happen with force". It was seen that Menderes applied the oppressive CHP policies which he criticized before he came to power, in the same way when he came to power. This seems to be in line with the assumption of Michels in the Bronze Law Theory of Oligarchy arguing that "no matter who is in power, the relations between the ruler and the ruled will continue as before, and the structure that seizes power will degenerate in any case". On the other hand, although Menderes had good relations with the economic elites of his time based on common interests, he could not establish positive relations with the military elites -and other elites of that period (e.g. universities and the press), which is seen as contrary to Mills' Power Elite Theory.

\section{CONFLICT OF INTEREST STATEMENT}

There is no conflict of interest between the authors.

6. FINANCIAL SUPPORT

The authors received no specific funding or support for this work

7. AUTHOR CONTRIBUTIONS

HÖ, CC : Idea; 
HÖ : Design;

HÖ: Check;

HÖ, CC: Collection and/or processing of resources;

HÖ, CC: Analysis and/or interpretation;

HÖ, CC: Literature review;

HÖ, CC: Writer;

HÖ: Critical review.

8. ETHICS COMMITTEE STATEMENT AND INTELLECTUAL PROPERTY COPYRIGHTS

Ethics committee principles were followed in the study. There has been no situation requiring permission within the framework of intellectual property and copyrights.

\section{REFERENCES}

Acar, M. \& Demir, Ö. (2005). Sosyal bilimler sözlüğ̈̈. Ankara: Adres Yayınları.

Ağaoğlu, S. (2016). Arkadaşım menderes: İpin gölgesindeki günler. İstanbul: Yapı Kredi Yayınları.

Ahmad, F. (1995). Modern türkiye’nin oluşumu,. Y. Alogan (Çev.). İstanbul: Sarmal Yayinevi.

Ahmad, F. (2010). Demokrasi sürecinde türkiye (1945-1980). A. F Yıldırım (Çev.), İstanbul: Hil Yayınları.

Akbal, İ. (2017). Farabî siyasi düşüncesinde toplum, devlet yönetimi ve siyasal rejim sorunu. https://www.kirmizilar.com/tr/index.php/konuk-yazarlar2/2376-Farabîsiyasi dusuncesinde-toplum-devlet-yonetimi-ve-siyasal-rejim-sorunu. Accessed: 29.05.2021.

Akşin, S. (2007). Kısa türkiye tarihi. İstanbul: Türkiye İş Bankası Kültür Yayınları.

Altaş, S. (2011). Çarıklı demokrasi. İstanbul: İkinci Adam Yayınları.

Altıntop, C. (2016). Ebû nasr el- farabî’nin ideal devlet anlayışı. Akademia Sosyal Bilimler Dergisi, 2(1), 48-62.

Alvarez-Manilla, J. M. (2018). La rebelión de las masas... hoy. https://www.researchgate.net/publication/328702146_LA_REBELION_DE_L AS_MASAS_HOY. Accessed: 18.10.2020.

Apuhan, R. Ş. (2007). 27 Mayls'tan yassiada mahkemelerine menderes: Resmi tarihi değiştirecek gerçekler. İstanbul: Timaş Yayınları.

Arnhart, L. (2013). Platon'dan rawls'a siyasi düşünce tarihi. A. K. Bayram (Çev.), Ankara: Adres Yayınları.

Arslan, D. Ali (2007). Elit sosyolojisi. Ankara: Phoenix Yayınevi.

Arslan, R. (2010). Elitizm teorisi ve teorisyenleri. Bursa: Dora Yayınları.

Aydemir, Ş. S. (2000). Ihtilalin mantı̆̆ ve 27 mayls ihtilali. İstanbul: Remzi Kitabevi.

Aydemir, Ş. S. (2004). Menderes'in dramı. İstanbul: Remzi Kitabevi.

Aydemir, S. Ș. (2011a). İkinci adam (1938-1950). İstanbul: Remzi Kitabevi.

Aydemir, S.Ş. (2011b). İkinci adam (1950-1964). İstanbul: Remzi Kitabevi. 
Bakan, S. \& Özdemir, H. (2013). Türkiye'de 1946-1960 dönemi iktidar-muhalefet ilişkileri: Cumhuriyet halk partisi (chp) demokrat parti (dp)'ye karşı. Cumhuriyet Universitesi İktisadi ve Ídari Bilimler Dergisi, 14(1), 373-397.

Bahce, H. E. (2008), Siyasette paradigma değişimi, siyasal katılım ve gençlik. https://tasam.org/tr-

TR/Icerik/779/siyasette_paradigma_degisimi_siyasal_katilim_ve_genclik. Accessed: 11.06.2021.

Bayar, C. (2010). Başvekilim adnan menderes. İstanbul: Truva Yayınları.

Başgil, A. F. (2014). 27 mayıs ihtilali ve sebepleri. İstanbul: Kubbealtı Neşriyat.

Birand, M. A., Dündar, C. \& Çaplı, B. (2016). Demirkırat: Bir demokrasinin doğuşu. İstanbul: Can Yayınları.

Bogdanor, V. (1999). Blackwell'in siyaset bilimi ansiklopedisi. B. Peker (Çev.). Ankara: Ümit Yayıncilik.

Bottomore, T. B. (1997). Seçkinler ve toplum. E. Mutlu (Çev.). Ankara: Gündoğan Yayınları.

Bozdağ, İ. (1975). Demokrat parti ve ötekiler. İstanbul: Kervan Yayınları.

Burçak, R. S. (1998). On yılın anıları (1950-1960). Ankara: Nurol Matbaacılık.

Çağla, C. (2015). Yeni başlayanlar için siyaset bilimi. İstanbul: Bilge Kültür Sanat.

Çizmeli, Ş. (2007). Menderes: Demokrasi yıldızı?. Ankara: Arkadaş Yayınevi.

Çubukçu, İ. A. (1977). İslam düşünürleri. Ankara: Ankara Üniversitesi İlahiyat Fakültesi Yayınlar1.

Çufalı, M. (2004). Türkiye'de demokrasiye geçiş dönemi (1945-1950). Ankara: Ebabil Yayınları.

Daver, B. (1993). Siyaset bilimi. Ankara: Siyasal Kitabevi.

Delican, M. (2012). Elite theories of pareto, mosca and michels. Journal of Social Policy Conferences, 43-44, (pp. 323-335).

Demir, Ş. (2009). Türk siyasi tarihinde adnan menderes (1930-1960). Yayımlanmamış doktora tezi, Marmara Üniversitesi, İstanbul.

Demir, Ş. (2010). Türk siyasi tarihinde adnan menderes. İstanbul: Paraf Yayınları.

Demirci, F. \& Önder, Ö. (2016). Bürokrasi. H. Çetin (Ed.) Siyaset bilimi içinde (ss.557618). Ankara: Orion Kitabevi.

Dilipak, A. (1990). Menderes dönemi. İstanbul: Beyan Yayınları.

Drochon, H. (2020). Robert michels, the 1ron law of oligarchy and dynamic democracy. Constellations, 27(2), 185-198.

Eroğul, C. (1990). Demokrat parti (tarihi ve ideolojisi). (2. Baskı), Ankara: İmge Yayınları.

Farabî (2001). İslam klasikleri el- medinetu'l fâzıla. N. Danışman (Çev.). Ankara: Millî Eğitim Bakanlığı Yayınları.

Güneş, G. \& Akdağ, M. (2013). Çok partili yaşama geçiş sürecinde adnan menderes'in aydın ilindeki siyasi faaliyetleri (1946-1950). Çăgdaş Türkiye Tarihi Araştırmaları Dergisi, 13(27), 185-224. 
Güvenç, B. (1995). Kültür ve demokrasi. İstanbul: Gündoğan Yayınları.

Haldun, İ. (2014). Mukaddime. S. Uludağ (Hazılayan). İstanbul: Dergâh Yayınları.

Hasanov, B. (2016). İbn haldun'da asabiyet kavramı-maurice halbwachs'1n "kolektif hafıza" kavramı ile bir karşılaştırma. Elektronik Sosyal Bilimler Dergisi, 15(59), 1437-1446.

Hajayneh, Mohammad F. (1987). Farabi ve siyasal düşüncedeki yeri. İstanbul Üniversitesi İktisat Fakültesi Mecmuası, 45(1-4), 519-524.

Heywood, A. (2014). Siyaset. B. B. Özipek vd. (Çev.). İstanbul: Adres Yayınları.

Heywood, A. (2016). Siyasetin ve uluslararası ilişkilerin temel kavramları. F. Bakırcı (Çev.). Ankara: BB101 Yayınları.

İnan, S. (2002). Muhalefette adnan menderes (1945-1950). Yayımlanmamış doktora tezi, Isparta Üniversitesi, Isparta.

Karpat, K. H. (2010). Türk demokrasi tarihi: Sosyal, kültürel, ekonomik temeller, İstanbul: Timaş Yayınları.

Kapani, M. (2012). Politika bilimine giriş. Ankara: Bilgi Yayınevi.

Karadaş, C. (2018). Siyasal elitizm teorileri ve güçlü demokratik elitizm modeli üzerine bir inceleme, Yayımlanmamış yüksek lisans tezi, Ardahan Üniversitesi, Ardahan.

K1sakürek, N. F. (1998). Benim gözümde menderes. İstanbul: Büyükdoğu Yayınları.

Kışlalı, A. T. (2002). Siyaset bilimi. Ankara: İmge Kitabevi.

Konca, Ö. F. (2011). Adnan menderes'in siyasal yaşamı ve kişiliği. Yayımlanmamış yüksek lisans tezi, Dokuz Eylül Üniversitesi, İzmir.

Kongar, E. (2006). 21. yüzyılda türkiye 2000'li yıllarda türkiye'nin toplumsal yapısı. İstanbul: Remzi Kitabevi.

Lewis, B. (1993). Modern türkiye’nin doğuşu. M. Kıratlı (Çev.). Ankara: Türk Tarih Kurumu Basimevi.

Lipset, S. M. (2008). Robert michels, demokrasi ve oligarşinin tunç kanunu. T. Dereli (Çev.). Çalışma ve Toplum, 4, 11-38.

Menderes, A. \& Akyol, T. (2011). Demokrasiden darbeye babam adnan menderes. İstanbul: Doğan Kitap.

Mert, N. (2007). Merkez să̆ın kısa tarihi. İstanbul: Selis Kitaplar.

Mosca, G. (2013). Siyaset biliminin temelleri. H. İleri (Çev.). İstanbul: Alter Yayınları.

Nietzsche, F. (2002). Güç istenci. Sedat Umran (Çev.). İstanbul: Birey Yayıncılık.

Nietzsche, F. (2003). Tan kızıllı̆̆ . Ö. S. Karadana (Çev.). İstanbul: Say Yayınları.

Ortega y Gasset, J. (2010). Kitlelerin ayaklanması. N. G. Işık (Çev.). İstanbul: Türkiye İş Bankası Yayınları.

Özbudun, E. (2010). Türk siyasal hayatı. L. Kılıç (Ed.). Eskişehir: Anadolu Üniversitesi Yayınları.

Özdemir, H. (2013), Demokrat parti (dp) ile adalet ve kalkınma partisi (akp)'nin ekonomi politikaları açısından karşılaştırılması. Uludă̆ Üniversitesi İktisadi ve İdari Bilimler Fakültesi Dergisi, 32(1), 11-51.

Öztekin, A. (2003). Siyaset bilimine giriş. Ankara: Siyasal Kitabevi.

Pareto, V. (1935). The mind and society. London: Harcourt, Brace and Company 
Platon (1992). Devlet. S. Eyüboğlu \& M. A. Cimcoz (Çev.). İstanbul: Remzi Kitabevi.

Popper, K. (1998). Açık toplum ve düşmanları. M. Tunçay (Çev.). İstanbul: Remzi Kitabevi.

Şenel, A. (1995). Siyasal düşünceler tarihi: Tarih öncesinde, ilkçăg'da, ortaçă̆'da ve yeniçağ'da toplum ve siyasal düşünüş. Ankara: Bilim ve Sanat Yayınları.

Şeyhanlığlu, H. (2011). Türk siyasal muhafazakarlı̆ı̆ın kurumsallaşması ve demokrat parti. Ankara: Kadim Yayınları.

Tannenbaum, D. G. \& Schultz, D. (2011). Siyasi düşünce tarihi filozoflar ve fikirleri. F. Demirci (Çev.). Ankara: Adres Yayınları.

Timur T. (2003). Türkiye'de çok partili hayata geçiş. Ankara: İmge Kitabevi Yayınları.

Tunçay, M. (2000). Türkiye tarihi 4 çağdaş türkiye 1908-1980. İzmir: Cem Yayınevi.

Türkdoğan, O. (2015). Türk toplumunda aydın sinıfin anatomisi. Konya: Çizgi Kitabevi.

Ünlü, N. Y. (2020). Demokrat parti'nin kurucularindan celal bayar ve adnan menderes' in liderlikleri: İ̧ siyasi olaylar üzerinden bir analiz. Yayımlanmamış yüksek lisans tezi, Ankara Hacı Bayram Veli Üniversitesi, Ankara.

Vergin, N. (2012). Siyasetin sosyolojisi: Kavramlar, tanımlar, yaklaşımlar. İstanbul: Doğan Kitap.

Walker, J. (1966). A critique of the elitist theory of democracy. The American Political Science Review, 60(2), 285-295.

Wallace, R. A. \& Wolf, Alison (2012). Çağdaş sosyoloji kuramları klasik geleneğin genişletilmesi. L. Elburuz \& M. R. Ayas (Çev.). Ankara: Doğu Batı Yayınları.

Yalçın, S. (2004). Efendi: Beyaz türklerin büyük sırrı. İstanbul: Doğan Kitap.

Yalçınkaya, A. (2012). Büyük sokratesçi okullar ve siyaset. M. A. Ağaoğulları (Ed.) Soktates'ten jakobenlere batı'da siyasal düşünceler içinde (ss. 91-125). İstanbul, İletişim Yayınları.

Yaşar, A. (2016). İbn haldun'a göre siyasi otorite ve liderlik. M. Balcı (Ed.) Geņ hukukçular hukuk okumaları birikimler $v$ içinde (513-527). İstanbul: Hukuk Vakfi Yayınları.

Yayla, A. (2003). Siyasi düşünce sözlüğü. Ankara: Liberte Yayınları.

Yetkin, Ç. (2014). Karşıdevrim: 1945-1950. Ankara: Kilit Yayınları.

Yıldız, M. (2014). Din-siyaset ilişsileri bağlamında farabî ve maturidi. S. Kutlu (Ed.) Uluslararası maturidilik sempozyumu bildirileri içinde (ss. 78-94). Ankara: Hoca Ahmet Yesevî Uluslararası Türk-Kazak Üniversitesi İnceleme-Araştırma Dizisi.

Zürcher, E. J. (2000). Modernleşen türkiye'nin tarihi. Y. Saner Gönen (Çev.). İstanbul: İletişim Yayınları. 